(2) norden 



\section{Beste tilgjengelige teknikker (BAT) for fiskeoppdrett i Norden}

Jostein Solbakken, Lars Windmar, Helge Liltved, Jo Inge Hesjevik, Ragnar JohannsonKortversjon

TemaNord 2008:546 


\section{Beste tilgjengelige teknikker (BAT) for fiskeoppdrett i Norden}

TemaNord 2008:546

Kortversjon

(C) Nordisk Ministerråd, København 2008

ISBN 978-92-893-1697-2

Trykk: Ekspressen Tryk \& Kopicenter

Opplag: 190

Trykt på miljøvennlig papir som oppfyller kravene i den nordiske miljøsvanemerkeordning.

Publikasjonen kan bestilles på www.norden.org/order. Flere publikasjoner på

www.norden.org/publikationer

Printed in Denmark

Nordisk Ministerråd

Store Strandstræde 18

1255 Copenhagen $\mathrm{K}$

Telefon (+45) 33960200

Fax (+45) 33960202

\section{Nordisk Råd}

Store Strandstræde 18

1255 Copenhagen $\mathrm{K}$

Telefon (+45) 33960400

Fax (+45) 33111870

www.norden.org

\section{Det nordiske samarbeidet}

Det nordiske samarbeid er en av verdens mest omfattende regionale samarbeidsformer. Samarbeidet omfatter Danmark, Finland, Island, Norge og Sverige, samt de selvstyrende områdene Færøyene, Grønland og Åland.

Det nordiske samarbeid er både politisk, økonomisk og kulturelt forankret, og er en viktig medspiller i det europeiske og internasjonale samarbeid. Det nordiske fellesskap arbeider for et sterkt Norden i et sterkt Europa.

Det nordiske samarbeid ønsker å styrke nordiske og regionale interesser og verdier i en global omverden. Felles verdier landene imellom er med til å styrke Nordens posisjon som en av verdens mest innovative og konkurransekraftige regioner. 


\section{Innhold}

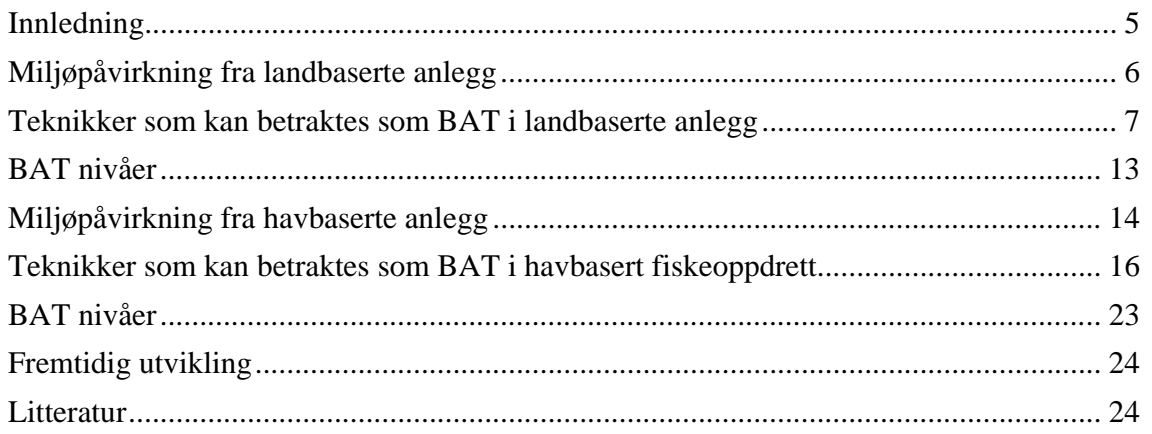

\section{Innledning}

Fiskeoppdrettsindustrien i Norden produserer fisk hovedsakelig til konsum, men også til utsett i innsjøer og farvann med truede eller nedadgående bestander. Det oppdrettes til sammen omkring 12 ulike marine- og ferskvannsarter. Produksjonen av disse artene representerer en betydelig andel av det årlige produksjonskvantum fra oppdrett i Europa. Fiskeoppdrett industriens miljøpåvirkning kjennetegnes av høyt energiforbruk til oppvarming, høyt vannforbruk og utslipp av organisk materiale og næringsstoffene fosfor og nitrogen.

Målet med dette heftet er å anbefale beste tilgjengelige teknikker (BAT) som reduserer forbruk av vann og energi, belastningen fra fôr og fekalier og forbruk av medisiner og kjemikalier i havbaserte og landbaserte fiskeoppdrettsanlegg.

Her er BAT definert som teknikker utprøvd i moderne fiskeoppdrett som reduserer utslipp og forbruk av ressurser og samtidig ivaretar fiskens helse og velferd. Det er samtidig forutsatt av teknikkene er mulig å implementere med hensyn til driftsmessige og økonomiske forhold.

Grunnlagsmateriale ble samlet fra et utvalg av landbaserte og havbaserte fiskeoppdrettsanlegg. Opplysninger ble også innhentet fra miljømyndigheter og utstyrleverandører av den aktuelle teknikken.

Teknikkene som representeres er integrert i referanseanlegg eller brukt som generelle tiltak i oppdrettsnæringen. Investeringskostnadene varierer mye mellom de nordiske land, og oppgitte verdier må derfor bare betraktes som veiledende.

Heftet er en kortversjon av rapporten Beste tilgjengelige teknikker (BAT) for fiskeoppdrett i Norden, Copenhagen, Nordic Council of Ministers, TemaNord 2005:528. 


\section{Miljøpåvirkning fra landbaserte anlegg}

De landbaserte fiskeoppdrettsanleggene i Norden varierer i størrelse fra jorddammer, der en produserer yngel til utsett for styrking av ville bestander, til store landbaserte anlegg for produksjon av matfisk. Arter som oppdrettes er Atlantisk laks, regnbueørret, røye, sjøørret, innlandsørret, sik, ål, gjørs, torsk, kveite, piggvar, flekksteinbit og havabbor.

Settefiskanlegg med utslipp til ferskvann hadde en produksjon på 79 mill yngel/settefisk, mens matfiskanlegg med utslipp til ferskvann produserte 38500 tonn fordelt på 7 arter (år 2000/2001).

Blant anlegg som hadde utslipp til sjøvann produserte settefiskanleggene $183 \mathrm{mill}$ yngel/settefisk, mens de landbaserte matfiskanleggene produserte 3094 tonn fordelt på 5 fiskearter (år 2000/2001).

Anlegg med utslipp til ferskvann er landbaserte klekkeri og settefiskanlegg, merdbasert oppdrett i ferskvann, dambasert oppdrett og landbaserte påvekstanlegg. Dambasert oppdrett står for det største produksjonskvantumet. Landbaserte anlegg med utslipp til sjøvann omfatter i hovedsak klekkerier og settefiskanlegg for laks og regnbueørret.

Et landbasert anlegg med klekkeri og påvekstanlegg inneholder følgende faser: hold av stamfisk, stryking av rogn fra stamfisk/naturlig gyting av rogn i kar, inkubering av egg, startfôring, yngelfôring og påvekst. Prosessene består av følgende; fôring, sortering, transport av fisk, vaksinering, medisinering, behandling mot parasitter, vasking av kar og rør, høsting og slakting.

Miljøkonsekvensene er i hovedsak beskrevet med bakgrunn i de prosesser som foregår i et landbasert settefiskanlegg for laks og regnbueørret siden disse anleggene representerer storparten av de landbaserte anleggene i Norden.

\section{Energiforbruk}

De landbaserte fiskeoppdrettene bruker energi til oppvarming og pumping av vann, belysning, oksygenproduksjon og - innløsning og UV behandling av inntaksvannet.

Mange anlegg har varmepumper der forholdet mellom avgitt energi til inntaksvannet og tilført energi til kompressor og pumper (systemeffektfaktor) ligger mellom 10 og 20. Det totale energiforbruket i landbaserte fiskeoppdrett varierer mye i og mellom de nordiske landene. Generelt varierer nivået mellom 0 og $60 \mathrm{kWh} / \mathrm{kg}$ produsert fisk avhengig av fiskeart, stadie i livssyklusen, om vannet varmes opp og i hvilken grad det resirkuleres. 
Vannforbruk

Vannet tilfører fisken oksygen og transporterer bort avfallstoffer. Ferskvannet taes i hovedsak fra tilknyttede vassdrag med tilstrekkelig nedslagsfelt.

Vannforbruket varierer også mye i anleggene i og mellom de nordiske land. Verdier varierer fra 6 til $160 \mathrm{~m}^{3}$ vann/kg fisk produsert. Det relative vannforbruket i land med lave ferskvannsforekomster og/eller høye avgifter på ferskvannet er lavere i forhold til land med høye ferskvannsforekomster.

\section{Forbruk av medisiner og kjemikalier}

Forbruk av medisiner og kjemikalier i landbasert oppdrett omfatter antibiotika, anestesimidler, fungisider, anthelmintika og andre parasittmidler som formalin.

Antibiotikaforbruket varierer fra 21 til 760 kg/år mellom de nordiske land. En medvirkende årsak til dette kan være behandling ved utbrudd av bakteriesykdommer som Flavobacterium psychrophilum og Ichthyophtihirius multifilis i ørretoppdrett som det ikke finnes vaksine mot.

\section{Utslipp av fôr og fekalier}

Avløpsvannet fra landbaserte klekkerier og matfiskanlegg består av fôrrester, fekalier, rengjøringsmidler og desinfiseringsmidler. Fôrrester og fekalier sedimenterer i resipienten. Størstedelen av fosforet tilføres miljøet $\mathrm{i}$ form av fôrspill og fekalier, mens nitrogen tilføres miljøet i oppløst form, der bare en mindre del er bundet til partikler. Av totalmengde nitrogen og fosfor som tilføres via fôret vil ca. $52 \%$ av nitrogenet og $63 \%$ av fosforet ende opp i miljøet dersom en tar utgangspunkt i en fôrfaktor på 1.04 .

Utslippene for næringssalter varierer mellom 15-70 kg nitrogen og 1$10 \mathrm{~kg}$ fosfor/tonn fisk produsert. Variasjonen tilskrives grad av resirkulering av vannet og anretninger for filtrering/tilbakeholdelse av fôrspill og fekalier i egne renseenheter i anlegget.

\section{Teknikker som kan betraktes som BAT i landbaserte anlegg}

Opplysningene i dette kapittelet er hentet fra følgende typer landbaserte fiskeoppdretts-anlegg:

1. Matfiskanlegg for regnbueørret med høy grad av resirkulering av vann

2. Settefiskanlegg for laks og regnbueørret med middels grad av resirkulering av vann 
3. Matfiskanlegg for piggvar med høy grad av resirkulering av vann

4. Settefiskanlegg for laks og regnbueørret med middels grad av resirkulering av vann

5. Matfiskanlegg for regnbueørret med sedimenteringsanlegg

6. Matfiskanlegg for regnbueørret med semiresirkuleringsanlegg

7. Settefiskanlegg for laks og regnbueørret med lav grad av resirkulering av vann

\section{Reduksjon av vannforbruk og energiforbruk}

Hvor mye en kan redusere vannforbruket avhenger av art og livsstadium. Liten fisk har høyere spesifikt oksygenforbruk, og er mindre tolerant for avfallstoffer fra stoffskiftet. Reduksjon i vannforbruket vil redusere mengden avløpsvann, noe som vil forenkle rensingen av avløpsvannet. Strømforbruket vil øke i forbindelse med intern pumping og grad av oksygeninnløsning.

Vannforbruket i landbaserte settefiskanlegg og matfiskanlegg kan reduseres ved innføring av følgende teknikker:

- I settefiskanlegg for laksefisk kan oksygeneringsanlegg og karbaserte luftere for $\mathrm{CO}_{2}$, gjøre det mulig å redusere ferskvanns-forbruket fra 100 til $53 \mathrm{~m}^{3} / \mathrm{kg}$ produsert smolt (Teknikk nr. 1, Tabell 1, Figur 1).

- Installasjon av en resirkuleringsteknikk med partikkelfilter, biofilter og oksygentilsetning, vil kunne redusere ferskvannsforbruket ytterligere ned til $6,3 \mathrm{~m}^{3} / \mathrm{kg}$ smolt produsert (Teknikk nr. 2, Tabell 1).

- Det laveste vann- og strømforbruk i produksjon av laksefisk fra 10 til 500 g oppnås ved å installere en resirkuleringsteknikk der det brukes mikrofiltrering, biofilter og bruk av luft til vanntransport og lufting av vannet. Oppnåelige ferskvannsforbruk vil da reduseres fra 100 til 0,06 $\mathrm{m}^{3} / \mathrm{kg}$ produsert fisk, mens strømforbruket vil ligge på $1,5 \mathrm{kWh} / \mathrm{kg}$ produsert fisk (Teknikk nr. 5, Tabell 1).

- I landbaserte påvekstanlegg for varmtvannsarter av marinfisk, kan en redusere vannforbruket fra 100 til $0,8 \mathrm{~m}^{3} / \mathrm{kg}$ produsert fisk ved å resirkulere vannet gjennom partikkelfiltrering, biofilter, denitrifikasjonsfilter, fosforfellingsanlegg og tilsetning av oksygen før det renner inn i fiskekarene (Teknikk nr. 6, Tabell 1,

- Figur 2). Strømforbruket vil da ligge på ca. $11 \mathrm{kWh} / \mathrm{kg}$ fisk produsert. 


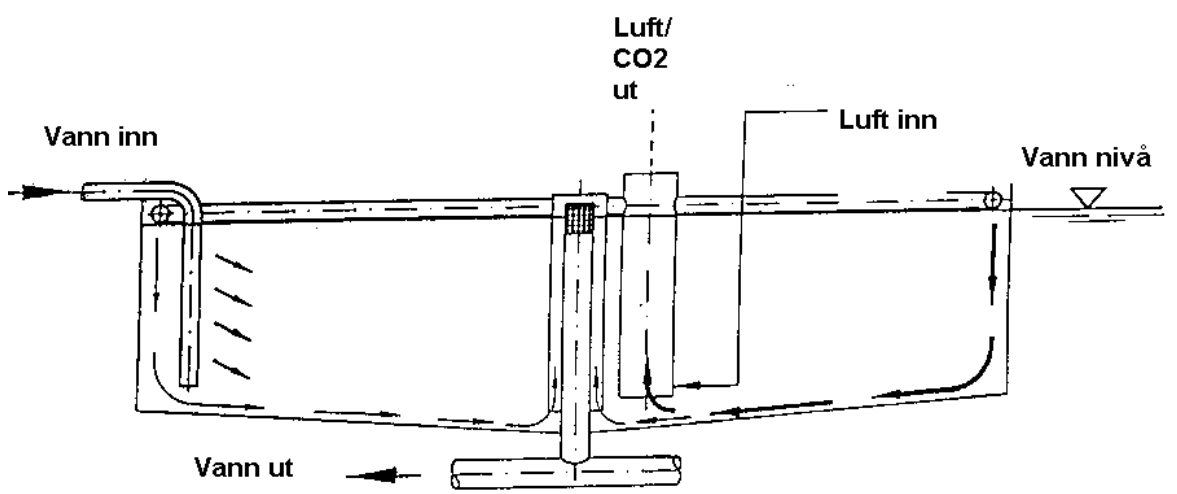

Figur 1. Skisse over teknikk der vannforbruk er redusert ved oksygenering og utlufting av karbondioksid.

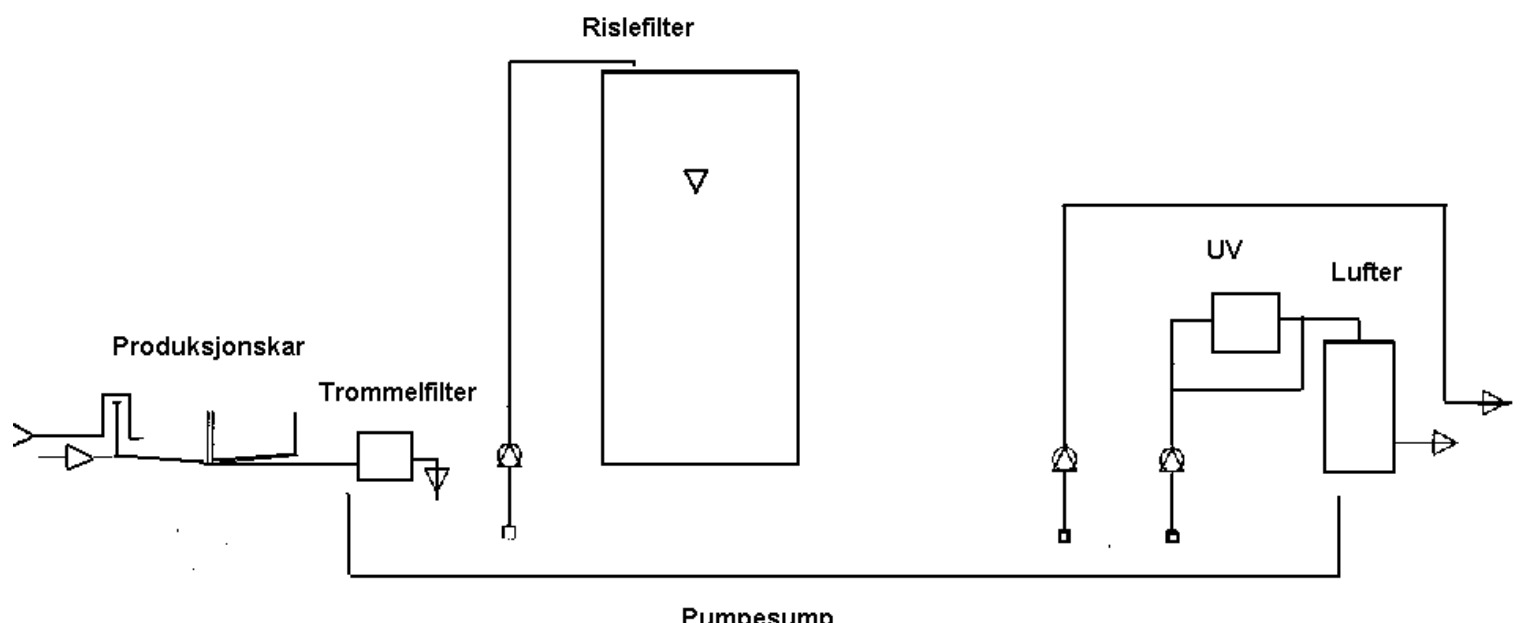

Pumpesump

Figur 2. Skisse over teknikk for høy grad av resirkulering av vann i påvekstanlegg for varmtvannsarter av marinfisk.

Pumping av vann

I fiskeoppdrett hvor en skal pumpe relativt store mengder vann over små løftehøyder, anbefales følgende:

- Bruk av sentrifugalpumper og propellpumper.

- Drive pumpene på midten av pumpekarakteristikken.

\section{Reduksjon i utslipp av organisk materiale}

Tiltak for å redusere forbruket av fôr

Reduksjon i fôrforbruket vil direkte påvirke utslippet av næringssalter. Fôrforbruket i landbaserte anlegg kan reduseres ved:

- Bruk av utfôringsanlegg som har fått inkorporert de nyeste vekstmodellene for laks eller andre fiskeslag. 
- Kobling av temperatursensorer til utfôringsanlegget for å logge vanntemperaturen kontinuerlig, og for å kunne regulere fôringen automatisk etter en predefinert modell. På denne måten vil systemet selv justere fôrtilgangen etter forholdene i karet.

- Bruk av en trakt som monteres i avløpet i karet for å registrere uspist fôr, der spillfôr registreres ved at en infrarød lysstråle blir brutt når fôrpelleter synker gjennom trakten.

- Bruk av fôringslogg tilknyttet utfôringsanlegget som tillater kontinuerlig læring gjennom analyse av historisk informasjon og får frem informasjon om når fisken spiser, hvor mye fisken spiser og hvor fort fisken spiser.

Oppsamling av fôrspill og fekalier

Følgende teknikker kan anvendes for å redusere utslipp av fôr og fekalier:

- Bruk av virvelseparatorer og partikkelfeller i avløp fra hvert kar og oppsamling av de oppfangede partiklene (Figur 3, teknikk nr. 2, Tabell 1).

- Installering av sedimenteringsbasseng før avløp (teknikk nr. 4, Tabell 1).

- Bruk av trommelfilter i forbindelse med avløpet (settefiskanlegg for laks) vil redusere utslipp av suspendert stoff fra fôrspill og fekalier med opp til $67 \%$ ved rutinedrift og opptil $94 \%$ ved uttapping eller «flushing» av kar.

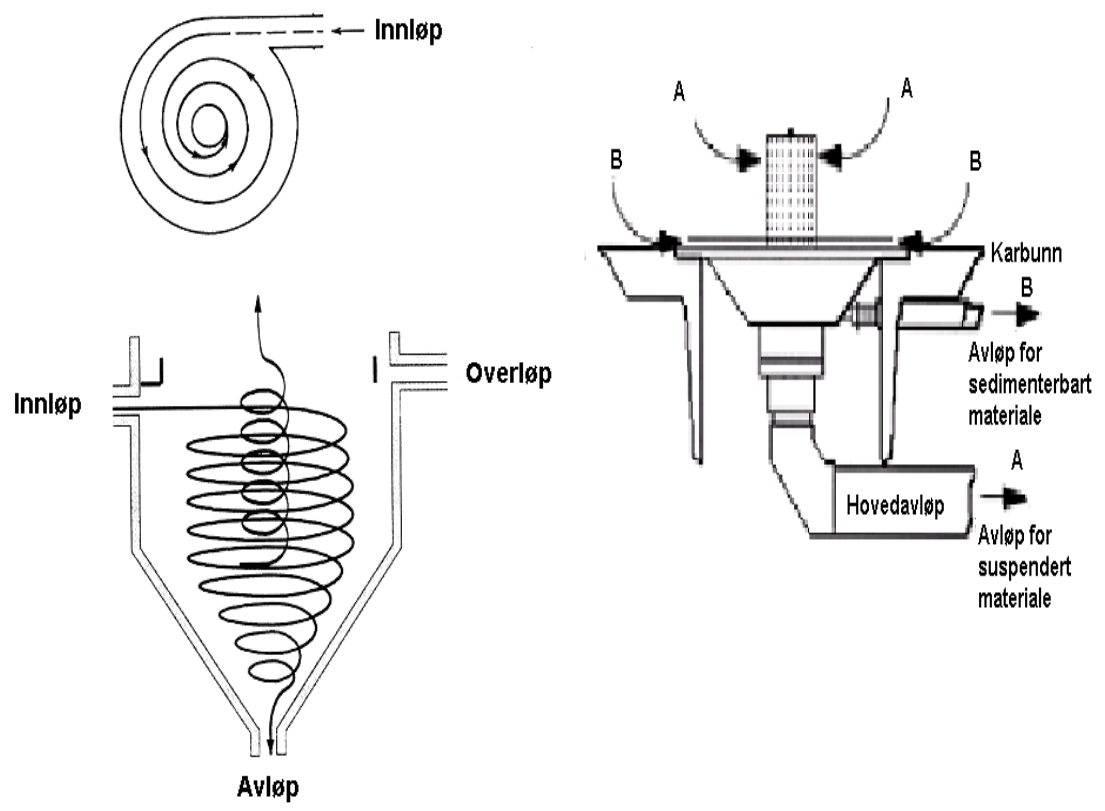

Figur 3. Hydrosyklon (t.v.) og partikkelfelle (t.h.), fungerer ved at sentrifugalkrefter og tyngdekrefter fører partiklene til senter av separatoren hvor det konsentrerte vannet føres til avløp, mens den klarfasen trekkes av via et overløp.

I et nordisk klekkeri og påvekstanlegg for 0,5 kg regnbueørret har en oppnådd svært lave utslipp av partikulært materiale og næringssalter ved å: 
- Bruke en resirkuleringsteknikk med finfiltrering av partikler, biofilter, nedsenkede luftebrønner og trykkluft for lufting og transport av vann (teknikk nr. 5, Tabell 1).

\section{Reduksjon i utslipp av oppløste eller svakt bundne ncringssalter}

Oppløste eller svakt bundne molekyler av nitrogen og fosfor i avløpsvannet lar seg ikke fjerne ved mekanisk filtrering eller sedimentering. Ved høy gjenbruksprosent av vannet, kan nitrat akkumuleres i resirkulasjonsanlegget. Bruk av et denitrifikasjonsfilter vil omdanne nitrat til nitrogengass som fritt vil avgasses til atmosfæren. Utslipp av næringssalter ytterligere reduseres ved å:

- Montere et denitrifikasjonsfilter i resirkuleringsanlegget, for å rense vannet for oppløste eller svakt bundne molekyler av nitrogen (teknikk nr. 3, Tabell 1).

- Montere et fosforfellingsenhet i resirkuleringsanlegget for å rense vannet for oppløste eller svakt bundne molekyler av fosfor. Oppnåelige nivå er ikke tilgjengelig (teknikk nr. 6, Tabell 1),

- fjerne flokkulerte partiklene fra fosforfellingsanlegg med et båndfilter (teknikk nr. 6, Tabell 1).

Slambehandling

Oppsamling av slam medfører en høy retensjon av partikkelholdig og løst bundet nitrogen og fosfor. Slambehandling kan anvendes på anlegg hvor mengden avløpsvann er liten i forhold til konsentrasjon av avfallstoff. Men;

- oppsamlet slam må behandles gjennom prosesser som fortykking (avvanning) og stabilisering før det kan brukes som jordforbedringsmiddel.

\section{Metoder for å sikre fiskens helsestatus}

I dette kapittelet vil bare de viktigste metodene omtales. Disse er behandling av inntaksvann, hygieneplaner/tiltak, vaksinering og regulering av fisketetthet.

Vannkvaliteten på inntaksvannet i nordiske landbaserte anlegg varierer svært mye, og det vil av den grunn ikke oppgis noen tallfestede verdier.

Følgende teknikker og metoder anbefales for å sikre helsestatus hos fisk i landbaserte anlegg:

- Bruk av stråledoser av UV som gir 99,9 \% inaktivering av fiskepatogene bakterier i inntaksvann.

- Bruk av tilstrekkelige restkonsentrasjoner av ozon som gir 99,9 \% inaktivering av virus i inntaksvann (ferskvann). 
- Fjerning av partikler i inntaksvannet gjennom mekanisk filtrering for å øke effekten av UV og ozondesinfisering av inntaksvannet og for å redusere gjelleirritasjoner hos fiskeyngel.

- Utarbeide hygieneplaner for å redusere sannsynlighet for smitte inn i anlegget, og mellom fiskebestander inne i anlegget. Denne omfatter plan over flyt av fisk og medarbeidere, bygging av hygienesluser mellom avdelinger, desinfeksjonsrutiner, rutiner på inntak av biologisk materiale av ukjent opprinnelse og utsending av fisk.

- Individuell vaksinering av all fisk som selges med aktuelle vaksiner og tilhørende vaksinasjonsstrategier. Vaksinering av laks og regnbueørret i oppdrett mot de mest hyppig forekommende bakteriesykdommene har medført en reduksjon i forbruk av antibiotika med opptil $99 \%$. Utgiftene øker med ca. $11 \%$ av total produksjonskostnad pr. smolt.

- Holde fisk under veiledende maksimaltettheter $\left(\mathrm{kg} / \mathrm{m}^{3}\right)$.

- Justere biomassen til et nivå der fisken i større grad får sitt oksygenbehov dekket gjennom vanngjennomstrømming heller enn fra oksygentilsetning.

Teknikker for å redusere utslipp av giftige og potensielt skadelige kjemikalier

For å redusere utslipp av giftige og potensielt skadelige kjemikalier, da spesielt rengjøringsmidler, kan følgende tiltak innføres:

- Holde alle overflater frie for fiskepatogene bakterier og virus.

- Bruke vaskemidler for å fjerne fettholdige lag for å maksimalisere effekten av desinfeksjonsmidler.

- Bruk av glatte overflater i kar, vegger og gulv.

- Bruk av kunstig lys for å redusere begroing på vegger og bunn i kar.

- Bruk av høytrykkspyling med «steamer» funksjon for å oppnå en høyere temperatur som gjør det lettere å gjerne fettholdige substanser på karveggene.

\section{Behandling av død fisk}

En vanlig teknikk for å konserve død fisk er syrekonservering i tank på anlegget. Anvendelse av teknikken, forutsetter infrastruktur og mottaksapparat for syrekonservert død fisk.

Teknikken reduserer nødvendigheten av lite miljøvennlig avhending og sikrer hygienisk oppbevaring av død fisk.

\section{Teknikker for å redusere rømming av fisk og skadelige effekter av rømming}

Rømming fra landbaserte anlegg er begrenset, men følgende tiltak kan innføres for å redusere sannsynlighet for rømming fra landbaserte anlegg: 
- Sikringstiltak i forbindelse med overføring av settefisk fra kar på land til brønnbåt som f. eks. sikring av transportslanger og håver.

- Installering av solide bunnsiler og installering av hindring før avløpet for å samle opp evt. rømmende fisk.

\section{BAT nivåer}

Oppsummerte nivåer ved anvendelse av teknikkene og metodene for landbaserte fiskeoppdrett som er beskrevet i denne rapporten er satt opp i Tabell 1. Nivåene som representeres vil variere med lokalitetsspesifikke forhold og må bare betraktes som veiledende. Investeringskostnadene varierer også mye mellom de nordiske land, og igjen bør oppgitte verdier bare betraktes som veiledende.

Tabell 1. Nitrogen og fosfor utslipp og vann- og strømforbruk i landbaserte anlegg ved valgte referanseanlegg.

\begin{tabular}{|c|c|c|c|c|c|c|c|}
\hline \multirow[t]{2}{*}{$\mathrm{Nr}$} & \multirow[t]{2}{*}{ Teknikk } & \multirow[t]{2}{*}{ Referanseanlegg } & \multicolumn{2}{|c|}{ Spesifikk belastning } & \multirow{2}{*}{$\begin{array}{r}\begin{array}{r}\text { Vannfor- } \\
\text { bruk }\end{array} \\
\begin{array}{r}\text { I/kg fisk } \\
\text { produ- } \\
\text { sert }\end{array}\end{array}$} & \multirow{2}{*}{$\begin{array}{r}\begin{array}{r}\text { Energi- } \\
\text { forbruk }\end{array} \\
\begin{array}{r}\mathrm{KWh} / \mathrm{kg} \\
\text { fisk } \\
\text { produ- } \\
\text { sert }\end{array}\end{array}$} & \multirow{2}{*}{$\begin{array}{r}\text { Referan- } \\
\text { se } \\
\text { anlegg }\end{array}$} \\
\hline & & & $\begin{array}{r}\text { Nitrogen } \\
\text { Kg/tonn } \\
\text { fisk produ- } \\
\text { sert }\end{array}$ & $\begin{array}{r}\text { Fosfor } \\
\text { Kg/tonn } \\
\text { fisk } \\
\text { produsert }\end{array}$ & & & \\
\hline 1 & $\begin{array}{l}\text { Oksygenering og } \\
\text { utlufting av } \mathrm{CO}_{2}\end{array}$ & $\begin{array}{l}\text { Settefiskanlegg for } \\
\text { laksefisk }(0,5-100 \\
\text { g), ferskvann. }\end{array}$ & 53,0 & 9,0 & 53000 & I.T. & 7 \\
\hline 2 & $\begin{array}{l}\text { Resirkulering med } \\
\text { partikkelfilter, biofilter } \\
\text { og oksygentilsetning }\end{array}$ & $\begin{array}{l}\text { Settefisk anlegg for } \\
\text { laksefisk }(0,5-100 \\
\text { g), ferskvann. }\end{array}$ & 40,0 & 4,0 & 6368 & 20,0 & 2 \\
\hline 3 & $\begin{array}{l}\text { Resirkulering med } \\
\text { partikkelfiltrering, } \\
\text { biofilter, denitrifi- } \\
\text { kasjonsfilter og oksy- } \\
\text { gentilsetning }\end{array}$ & $\begin{array}{l}\text { Matfiskanlegg } \\
\text { laksefisk }(10-500 \mathrm{~g}) \\
\text { ferskvann. }\end{array}$ & 18,0 & 8,5 & 123 & 5,4 & 1 \\
\hline 4 & $\begin{array}{l}\text { Sedimenteringsanlegg } \\
\text { ved avløp }\end{array}$ & $\begin{array}{l}\text { Matfiskanlegg } \\
\text { laksefisk }(10-500 \mathrm{~g}) \text {, } \\
\text { ferskvann. }\end{array}$ & 15,0 & 1,0 & 120 & I.T. & 5 \\
\hline 5 & $\begin{array}{l}\text { Resirkulering med } \\
\text { finfiltrering av partikler, } \\
\text { biofilter og lufting og } \\
\text { transport vha. trykkluft }\end{array}$ & $\begin{array}{l}\text { Matfiskanlegg } \\
\text { laksefisk }(10-500 \mathrm{~g}) \text {, } \\
\text { ferskvann. }\end{array}$ & 2,8 & 0,1 & 56 & 1,5 & 6 \\
\hline 6 & $\begin{array}{l}\text { Resirkulering med } \\
\text { partikkelfiltrering, } \\
\text { biofilter, denitrifi- } \\
\text { kasjonsfilter, fosforfel- } \\
\text { lingsanlegg og oksy- } \\
\text { gentilsetning }\end{array}$ & $\begin{array}{l}\text { Matfiskanlegg for } \\
\text { flatfisk (Piggvar, 10- } \\
500 \text { g), sjøvann. }\end{array}$ & I.T. & I.T. & 840 & 11,4 & 3 \\
\hline
\end{tabular}

Ved implementering av disse teknikkene må det presiseres at utslippsnivåene vil variere med fiskeart, kvalitet av vannkilden, fôringsrasjon etc. De oppgitte verdiene vil derfor bare være veiledende. I.T. = data ikke tilgjengelig. 


\section{Utslipp fra fôr og fekalier}

Partikkefeller på avløpet med oppsamling av slam i settefiskanlegg for laksefisk vil for partiklene kan man oppnå et utslipp på 40 kg nitrogen/tonn og $4 \mathrm{~kg}$ fosfor/tonn fisk produsert. Bruk av et teknikk nr. 3 vil redusere nitrogen utslippene fra 45 til $18 \mathrm{~kg} /$ tonn fisk produsert (Tabell 1). En ytterligere reduksjon i utslipp av fosfor kan oppnåes ved implementering av teknikk nr. 6, (Tabell 1), men oppnåelige nivå er dessverre ikke tilgjengelig. I teknikk nr. 5, (Tabell 1) oppnår man en reduksjon i utslippsnivå av nitrogen fra 52 til 2,8 kg/tonn fisk produsert og fosfor fra 9 til $0,1 \mathrm{~kg} /$ tonn fisk produsert.

Til en sammenligning ligger de nåværende gjennomsnittlige utslippene fra landbasert fiskeoppdrett i Norden på $55 \mathrm{~kg}$ nitrogen og 8 kg fosfor/tonn fisk produsert.

Ved implementering av teknikker som beskrives i Tabell 1, må det presiseres at utslippsnivåene vil variere med fiskeart, kvalitet av vannkilden, fôringsrasjon etc. De oppgitte verdiene vil derfor bare være veiledende.

\section{Forbruk av strøm og vann}

I settefiskanlegg for laksefisk der en benytter teknikk 1 kan en redusere vannforbruket fra 100 til $53 \mathrm{~m}^{3} / \mathrm{kg}$ produsert smolt (Tabell 1). Bruker man teknikk 2, kan man redusere vannforbruket ned til $6,3 \mathrm{~m}^{3} / \mathrm{kg}$ smolt produsert (Teknikk nr. 2, Tabell 1). Strømforbruket vil imidlertid øke i forbindelse med intern pumping og høy grad av oksygeninnløsning. For produksjon av laksefisk fra 10 til $500 \mathrm{~g}$ kan en oppnå et vannforbruk på $0,06 \mathrm{~m}^{3} / \mathrm{kg}$ produsert fisk, og et strømforbruk på $1,5 \mathrm{kWh} / \mathrm{kg}$ fisk produsert (Teknikk nr. 5, Tabell 1). I landbaserte påvekstanlegg for marin fisk, kan en oppnå et vannforbruk på $0,8 \mathrm{~m}^{3} / \mathrm{kg}$ produsert fisk (Teknikk nr. 6 , Tabell 1). Strømforbruket vil da ligge på ca. $11 \mathrm{kWh} / \mathrm{kg}$ fisk produsert.

\section{Miljøpåvirkning fra havbaserte anlegg}

Av de 7-10 artene som produseres i Norden var totalt produksjonskvantum 529000 tonn fordelt på 1162 anlegg (år 2000). Størsteparten av produksjonen bestod av norsk laks og regnbueørret.

I havbaserte anlegg settes det ut yngel og settefisk som fôres opp til slakt. Gjennom denne fasen gjennomføres prosesser som fôring, plukking av død fisk, skifte av merder, vasking av merder, behandling mot parasitter, behandling mot sykdommer og høsting av fisk til slakt.

Miljøpåvirkningen fra havbaserte oppdrettsanlegg stammer fra fôrforbruk, utslipp av fôr og fekalier, forbruk av medisiner, forbruk av giftige og potensielt giftige kjemikalier, død fisk og rømming, avfall og lukt og støy. 
Fôrforbruk

Fôrforbruket i de enkelte land har direkte sammenheng med det årlige produksjonskvantum. I 2001 var fôrforbruket i Norge 659.311 tonn, på Færøyene 81000 tonn og på Åland 6300 tonn.

\section{Forbruk av medisiner og kjemikalier}

I definisjon av medisiner er det kun tatt med antibiotika. Antibiotika blir bare brukt ved akutt behandling av fisk som har fått bakteriesykdommer. Forbruket av antibiotika i Norden varierer mellom 0,005 og 102 g pr. tonn fisk produsert, og er lavest på Åland og høyest i Danmark.

Kjemikalier som benyttes er bedøvelsesmidler, soppmidler, parasittmidler inkludert lakselusmidler, kobber, desinfeksjonsmidler og rengjøringskjemikalier. I 2001 ble forbrukt 201 tonn kobber i Norge og 31 tonn på Færøyene. Av ulike lakselusmidler ble det forbrukt 119 kg i Norge og 13,4 kg på Færøyene.

\section{Utslipp av fôr og fekalier}

Organisk utslipp omfatter fôr, fekalier, nitrogen og fosfor. Utslipp av partikler som sedimenterer på bunn er avhengig av dybde og strømforhold under oppdrettsenheten.

Størrelsen på fosforutslippene er først og fremst avhengig av mengden fôrspill og fekalier. Størrelsen på utslipp av nitrogen er også avhengig av mengden fôrspill og fekalier, men også av innholdet av protein i fôret. Størstedelen av nitrogenet tilføres miljøet i oppløst form, mens størstedelen av fosforet tilføres ved fôrspill og fekalier.

Danmark har det laveste gjennomsnittlige utslippet med $45 \mathrm{~kg}$ nitrogen og $5 \mathrm{~kg}$ fosfor pr. tonn fisk produsert. Sverige og Finland har det høyeste med $59 \mathrm{~kg} \mathrm{~N}$ og 7-8 kg fosfor pr. tonn fisk produsert. Noen finske anlegg er nede i $36 \mathrm{~kg}$ nitrogen og 4,3 kg fosfor/tonn fisk produsert.

\section{Rømming}

Rømming av fisk fra anlegg er et stort problem. Fra norske oppdrettsanlegg rømte det i år 2000 ca. 351000 laks og regnbueørret, mens det fra færøyske anlegg rømte ca. 1000000 laks i 2002.

\section{Avfall, lukt og støy}

Avfallsproblematikken er den samme som for landbaserte anlegg.

Lukt fra merdanlegg har sin kilde i fôr, død fisk, døde fastsittende organismer på notposen som henger til tørk og manglende renhold. Eventuell støy fra anlegg i sjø begrenser seg til motorlyd fra båter som transporterer personell og brønnbåter og båter som leverer fôr. Fôringsanlegg kan 
generere noe lyd. Dette er ikke vedvarende lyder, men oppstår sporadisk gjennom dagen og årstid. Strømgeneratorer kan også generere støy, men nyere generatorer er godt lydisolert og medfører ikke et vesentlig støyproblem. Noen anlegg har vaskemaskin for vask av notposer på anlegget som kan generere noe støy, men ikke over $40-50 \mathrm{~dB}(\mathrm{~A})$.

\section{Teknikker som kan betraktes som BAT i havbasert fiskeoppdrett}

Opplysninger og data i dette kapittelet er samlet inn fra følgende anlegg:

1. Matfiskanlegg for laks og regnbueørret med sensorsystemer for deteksjon av endring i spiseadferd og fôrspillmengder

2. Matfiskanlegg for laks og regnbueørret med oppsamlingssystem for fôrspill og død fisk

3. Matfiskanlegg for laks og regnbueørret med bruk av leppefisk for avlusing

4. Matfiskanlegg for laks og regnbueørret med automatisert system for skifte av notposer.

\section{Teknikker som reduserer utslipp av organisk materiale}

I havbaserte anlegg, vil den største reduksjonen i miljøutslipp oppnås ved å redusere fôrspill, fordi fôrspill har en høyere synkehastighet enn fekalier, og vil dermed sedimentere mer konsentrert under anlegget. Følgende teknikker kan bidra med å redusere utslipp av organisk materiale og belastning på resipient:

- Bruk av utfôringsanlegg der en har programmert inn vekstmodeller som tar hensyn til temperatur, daglengde og som har sensorer som er installert over eller under bunn av notposen og registrerer uspist fôr og fiskens aktivitet (figur 4).

- Bruk av system for oppsamling av fôrspill og død fisk som ellers vil belaste bunnen/miljøet under anlegget (figur 5). Kontinuerlig oppsamling av død fisk for å sikre helsetilstanden til den øvrige biomas 


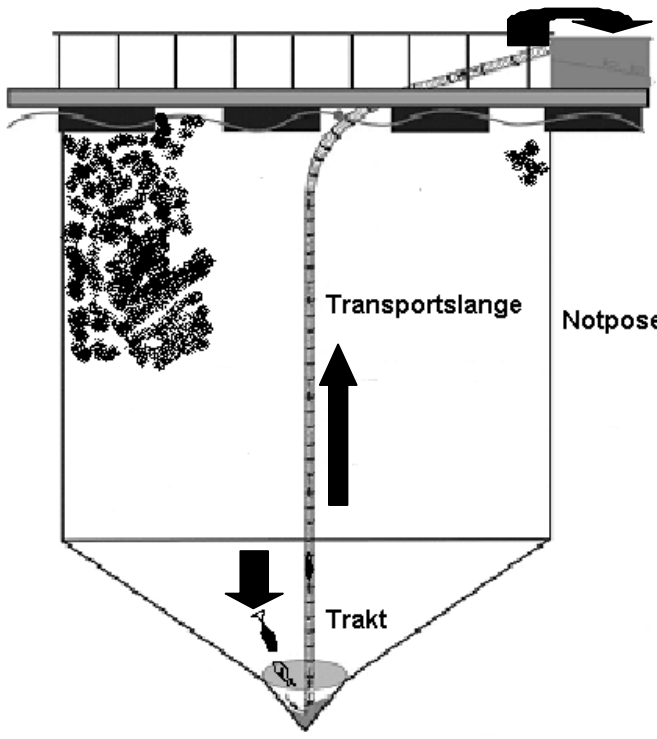

Silkasse

Mæranlegg

Figur 4. Prinsippskisse over oppsamlingssystem for fôrspill, fekalier og dødfisk.
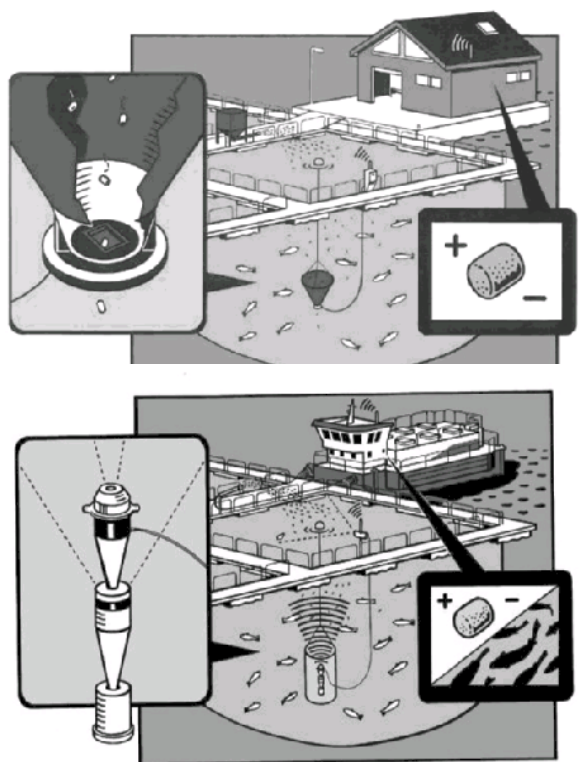

Figur 5. Prinsippskisse over havbasert oppdrettsanlegg med fôringsanlegg med infrarød (over) og doppler sensor (under) for deteksjon av fôrspill.

Teknikker som sikrer god helsestatus hos den stående biomasse

Følgende teknikker kan bidra til å sikre god helsestatus hos fisk i oppdrettsanlegg;

- Tilpasning av fisketetthet etter strømhastighet og temperatur på hver enkelt lokalitet. 
- Hyppig overvåking av konsentrasjoner av miljøparametre som ammoniakk og oksygen på ettersommeren og høsten, spesielt på strøm lokaliteter med liten vannutskifting.

- Bruk av leppefisk (figur 6) som beitere på lakselus i områder der det finnes større forekomst av vill leppefisk.

- Synkroniserte, regionale avlusninger, eksempelvis om våren for å fjerne mest mulig av den kjønnsmodne lusa før temperaturen og dermed lusens reproduksjonsevne stiger.

- Bruk av nedsenket lys i merdene i stedet for overflatelys for å bidra til at laksen fordeler seg dypere i merden gjennom hele døgnet, noe som fører til reduserte lusepåslag.

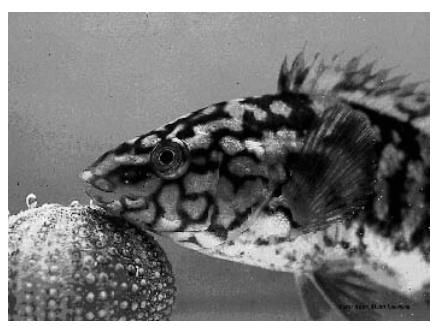

Figur 6. Berggylte

\section{Teknikker som reduserer utslipp av kjemikalier}

Av de kjemikalier som brukes i havbaserte anlegg, er det kobberimpregnering som det forbrukes mest av. Følgende teknikker kan redusere/eliminere bruk av kobberimpregnering;

- Tørking av notposer for å fjerne begroing ved å benytte seg av et dobbelt sett med notposer, der den ene posen trekkes opp og tørkes, mens den andre står i sjøen.

- Bruk av elektrisk drevne tromler som er montert på hver side av merden (figur 7) på større anlegg for å forenkle merdskifte og stimulere til hyppigere skifter på større notposer,

- Høytrykkspyling av de øverste 2-3 metrene av notposen mens den står i sjøen med spesialutviklet utstyr som kobles til vanntilførsel med høyt trykk (

- Figur 8). 


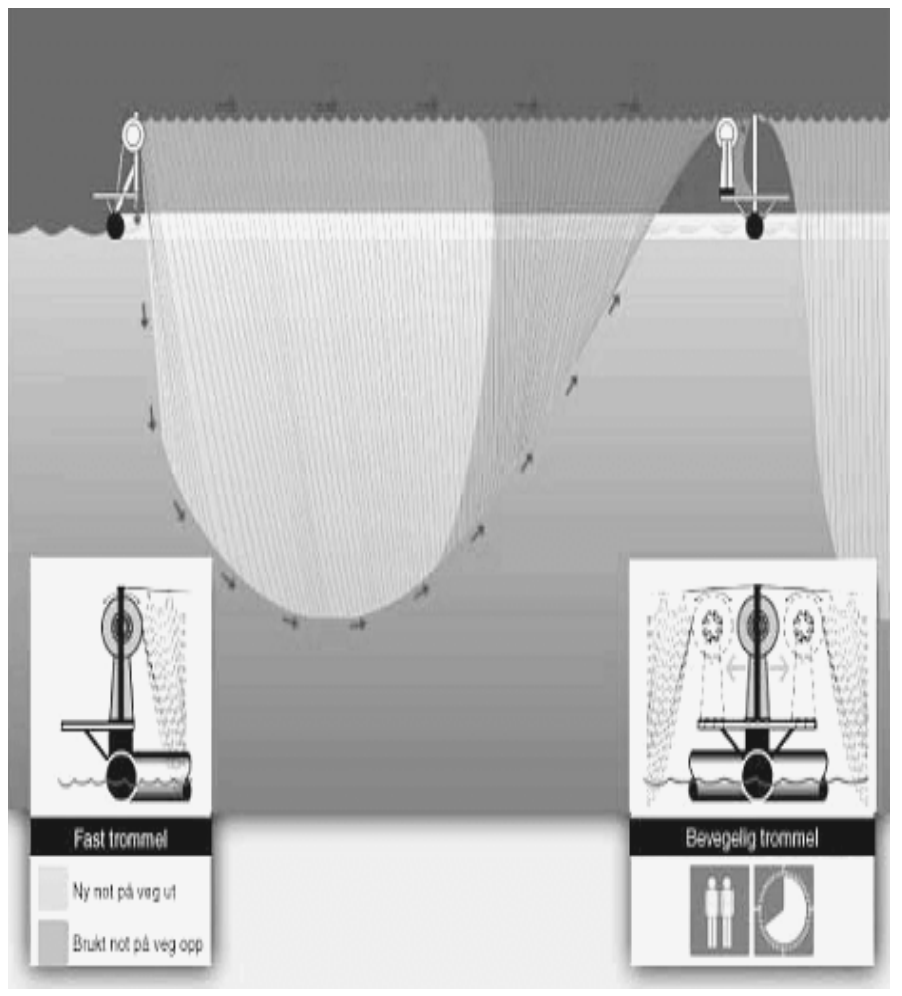

Figur 7. Prinsippskisse over teknologi for automatisk skifte av notpose i et havbasert matfiskanlegg.

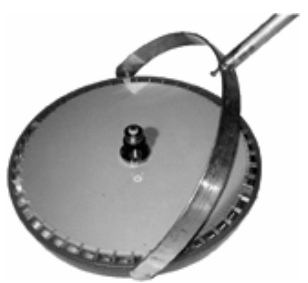

Figur 8. Vaskemaskin for vasking av veggen av notposer.

Teknikker som reduserer rømming av fisk og skadelige effekter av rømming

En spesifikk anleggsteknikk velges ut fra lokalitetens eksponeringsgrad f. eks. vindstyrke og bølgehøyde. I Norge er det innført et godkjenningssystem for flytende anlegg og en nasjonal standard for flytende oppdrettsanlegg (NS9415 - Flytende oppdrettsanlegg. Krav til utforming, dimensjonering, utførelse, installasjon og drift). Standarden ble iverksatt 1.4.2004. Hensikten med standarden er å redusere risiko for rømming som følge av teknisk svikt og feilbruk av oppdrettsanlegg. Alt utstyr som skal benyttes etter standardens iverksettelse skal være produktsertifiserte, mens eksisterende oppdrettsanlegg må få utstedt et dugelighetsbevis innen 2006. Dette dokumenterer forsvarlig teknisk standard på anlegget. Eksempel på ulike anlegg som nyttes på eksponerte lokaliteter Figur 9 og Figur 10). 


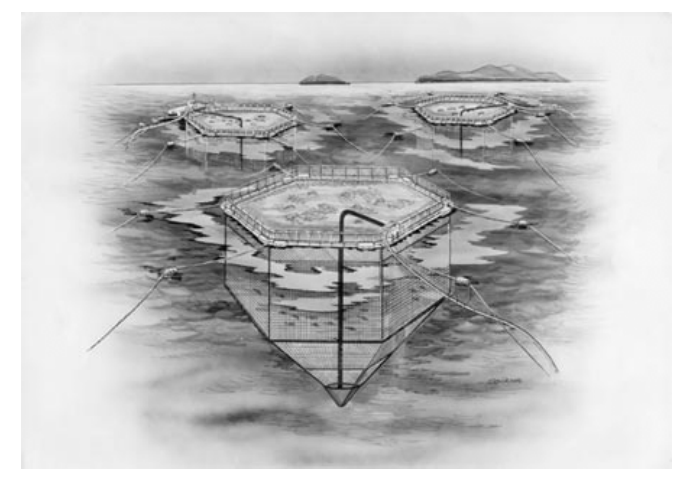

Figur 9. Havmerder laget av gummimateriale.

NS 9415 angir også krav til sammensetning, montasje, materialstyrke og kontroll/reparasjon av notposer som skal benyttes i flytende oppdrettsanlegg. Videre angir standarden de krav som stilles til brukerhåndbok for notposer. For å redusere sannsynlighet for rømming av fisk bør følgende tiltak innføres i havbaserte oppdrettsanlegg;

- Kontroll av notposen og utvikling av detaljerte prosedyrer for håndtering, kontroll av notpose før og etter utsetting, for montering $\mathrm{i}$ anlegget og for driftsrutiner (som f.eks. ved båtanløp).

- Sikring mot havari ved kollisjon med nyttetrafikk med tilstrekkelig belysning av anlegget, i tillegg til blinkende lanterner, spesielt under dårlig sikt.

- Regelmessige inspeksjoner og vedlikehold av fortøyninger og notposer for å kunne avdekke hull i notposene og svekkelser i fortøyninger og forankringer av anlegget.

- Hyppig notskifte for å gi god kontroll med tilstanden til nøtene.

- Regelmessig kontrollfiske med garn for å kunne detektere rømming av fisk raskt.

- Utvikling av rutiner for båtanløp ved levering av settefisk, avlusing, skifte av notposer, transport av fôr og ved høsting. 


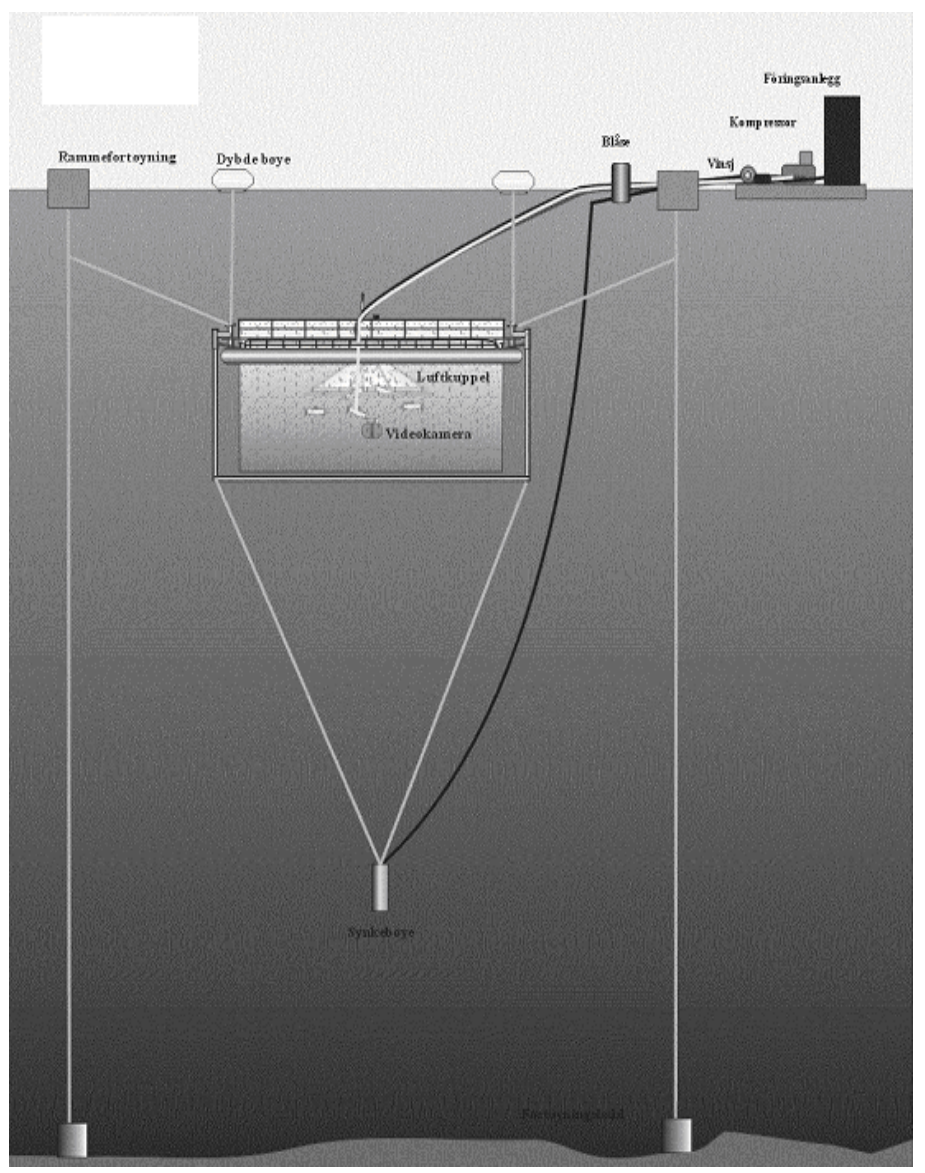

Figur 10. Prinsippskisse over nedsenkbar merd for produksjon av lakse- eller torskefisk.

\section{Teknikker som reduserer støy}

Støy fra merdbaserte oppdrettsanlegg vil komme fra strømaggregater, dødfisk kverner og evt. vaskemaskiner dersom anleggene vasker nøtene sine selv. Følgende tiltak vil redusere støy fra havbaserte oppdrettsanlegg;

- Bruke stillegående og isolerte strømaggregater.

- Tørking av notposer i stedet for bruk av vaskemaskin på anlegget, spesielt dersom anlegget ligger i nærheten av bebyggelse.

- Plassere utfôringspunktet under vann for å redusere støy ved utfôring av tørrfôr, dersom fôringssystemet tillater det.

\section{Estetikk}

Med hensyn til andre brukerinteresser av områdene oppdrettsanleggene er lokalisert i, bør følgende tiltak foretaes for å redusere iøyenfallenheten av anlegget; 
- Fortøyningsblåser bør ikke være av en farge som sjenerer omgivelsene.

- Fortøyninger bør være lagt i et system som er iøynefallende.

- Belysning av anlegget bør være slått av om natten med unntak av belysning for å styre biologiske prosesser som kjønnsmodning og markeringslys.

- Belysning for styring av biologiske prosesser bør være nedsenket under havoverflaten.

\section{Teknikker for lokalisering av anlegg og overvåkning av miljøtilstanden}

Optimal lokalisering av oppdrettsanlegg er en nøkkelforutsetning for å kunne drive lønnsomt. Ved lokalisering av anlegg må følgende taes i betraktning;

- Det må gjøres en faglig vurdering av lokalitetens årsvariasjoner i miljøforhold opp mot oppdrettsartens miljøkrav.

- Det bør være ingen eller redusert oppdrettsvirksomhet innenfor en sone på 1-5 km.

- En bør ikke lokalisere anlegg til terskelfjorder og strømsvake terskelbasseng.

- En strømhastighet på $5 \mathrm{~cm}$. pr. sek. eller mer er anbefalt for å sikre tilstrekkelig tilførsel av oksygen til fisken og spredning av avfallsstoffer. Ved lave fisketettheter kan kravet til vannutskifting reduseres noe.

Metoder for å ivareta bunnforholdene på en lokalitet og for overvåkning av sedimenttilstanden

Generasjonsdrift og brakklegging av hver oppdrettslokalitet betyr at hvert sjøanlegg må disponere 3-4 lokaliteter som brukes vekselvis. I konseptet holdes generasjoner atskilt på ulike lokaliteter og en lokalitet ligger alltid brakk.

Generasjonsdrift reduserer sykdomsmitte mellom generasjoner som settes i havet, og brakklegging av en lokalitet gjennom driftssyklusen muliggjør en rekonstituering av bunnfaunaen under et anlegg, og en unngår utvikling av anoksiske forhold som ofte resulterer i utvikling av gasser som metan og hydrogensulfid, som igjen er direkte giftig for fisk.

Når bunndyrsammensetningen er kommet opp på et akseptabelt nivå, kan fisk settes ut på den aktuelle lokaliteten. For å ivareta bunnforholdene på en lokalitet, anbefales det:

- Overvåkning av sedimenttilstanden ved MOM (Matfiskanlegg - overvåkning - modellering) som er et system som kan brukes til å regulere miljøpåvirkningen fra marine oppdrettsanlegg etter bæreevnen på lokaliteten (NS 9410),.

- Vurdering av sedimenttilstanden ut i fra grenseverdier for innhold av kobber og sink etter gitte regningslinjer. 
- Bruk av generasjonsdrift og brakklegging av lokalitet for å redusere sykdomsmitte mellom generasjoner og for å unngå anoksiske forhold under et anlegg.

- Vurdering av brakkleggingsperiodens lengde ut i fra bunndyrsammensetningen og totalt organisk karbon (TOC) i sedimentene, da det er en nær sammenheng mellom TOC og bunndyrsammensetning.

\section{BAT nivåer}

Nivåene som representeres i dette kapittelet vil variere med lokalitetsspesifikke forhold og må bare betraktes som veiledende. Investeringskostnadene varierer også mye mellom de nordiske land, og igjen bør oppgitte verdier bare betraktes som veiledende.

\section{Utslipp fra fôr og fekalier}

Selv om enkelte oppdrettsmyndigheter i de nordiske land har innført en begrenset mengde fôr til hver tillatelse, reduseres forbruk av fôr i hovedsak ved bruk av teknikker som detekterer fôrspill og overvåker fiskens aktivitet og vertikale fordeling. Slike systemer resulterer i at en kan oppnå en fôrfaktor under 1,00. Dette kan få utslippene av nitrogen og fosfor ned i henholdsvis $45 \mathrm{~kg} \mathrm{~N} /$ tonn og $5 \mathrm{~kg}$ P/tonn fisk produsert. En teknikk som samler opp fôrspill i bunn av notposen og transporterer det opp til overflaten sammen med død fisk, vil redusere utslippene ned til tilsvarende nivå som ved bruk av utfôringsanlegg som detekterer fôrspill. Videre vil den sistnevnte teknikken redusere den organiske belastningen på lokaliteten fordi både fôrspill og fekalier blir samlet opp.

\section{Forbruk av medisiner og kjemikalier}

Forbruk av medisiner, i hovedsak antibiotika, er oppe i $102 \mathrm{~g} /$ tonn fisk produsert i Danmark sammenlignet med 0,005-1g/tonn fisk produsert i resten av Norden. Årsaken til det høye forbruket av antibiotika i Danmark skyldes høye antall utbrudd av furunkulose og rødmunnsyke. I Danmark vaksineres bare 20-25\% av all fisk som settes ut i sjøen, mens i resten av Norden er andelen opp mot $100 \%$. Kjøp av settefisk som er individuelt vaksinert mot de fiskepatogene sykdommer som er vanlige i Norden, kan redusere forbruket av antibiotika med over $99 \%$.

Forbruk av avlusningsmidler i oppdrett av laks og regnbueørret kan utelukkes ved bruk av leppefisk. Dette er en teknikk som kun benyttes i Norge. Dette har sammenheng med at større mengder av de ulike leppefiskartene som brukes for lusekontroll bare finnes i Norge.

Tørking av notposer reduserer nødvendigheten av å impregnere med kobberholdige midler, og kan dermed utelukke bruken av kobber. Den 
ene merden henger til tørk, mens den andre er i bruk. For store stålanlegg finnes det automatiserte teknikker som letter arbeidet med notskifte. Den automatiserte teknikken kan imidlertid ikke brukes på store runde plastringer. Til slike merder finnes det høytrykkbaserte vaskemaskiner som fjerner begroing i de 2-3 øverste metrene mens notposen står i sjøen. Teknikken kan utføres fra merdkanten. Vasking av notposen dypere enn tre meter krever bistand fra yrkesdykkere.

\section{Rømming}

Teknikker som kan bidra til redusert rømming kan være tilpasning av anleggskonstruksjon til lokalitetens eksponeringsgrad og bruk av nedsenkbare merder ved spesielt eksponerte lokaliteter. Andre teknikker som rutinekontroll av notpose, sikring mot trafikk, vedlikehold av anlegg, hyppig notskifte, kontrollfiske med garn og rutiner for båtanløp kan bidra med å redusere rømming med opp til $100 \%$.

\section{Fremtidig utvikling}

Nåværende forskning og utvikling på teknikker for å redusere miljøpåvirkning fra fiskeoppdrett omfatter blant annet:

- utvikling av rimelige metoder for resirkulering av vann, oppsamling av fekalier, slamhåndtering, etterbehandling av slam, reduksjon i vannforbruk og forbruk av medisiner og hjelpestoffer i oppdett av regnbueørret(Danmark),

- utvikling av en lukket merd med tilknyttet renseenhet som foreløpig har gitt en utslippsreduksjon av fosfor på 90 \% (Finland),

- forsøk på å anvende ensilert død fisk til fremstilling av fargestoff og gjødsel (Finland),

- utvikling av vannbehandlingsanlegg i produksjon av marine fiskeyngel (Norge),

- optimal lokalisering av oppdrettsanlegg (Norge og Finland),

- egnethetsanalyser for oppdrett av laks og regnbueørret forhold til tidevannstrøm og bølger (Færøyene).

\section{Litteratur}

Beste tilgjengelige teknikker (BAT) for fiskeoppdrett i Norden, Nordic Council of Ministers, TemaNord 2005 